studied in this paper before the cross sections of bent yarn are studied. The circular cross section of the original fiber becomes ellipse when it is bent and the ratios of its diameter to the radius of curvature are nearly equal to 1 , although it varies with the kind of fiber and its denier. When the ratio go over 1 , the sections take the form of beans; in the case of below 1 , they remain nearly circle.

第 7 報 曲 ザ繊維の応力分布

(1958 年 9 月 12 日受理)

$$
\text { 辁 木恵 }
$$

\begin{abstract}
要旨織物がしわをつくられた状飶にあるとき，そのしわのある局部的瀻維は折り曲げの状態にあ るわけである。これについてさきに村上はレオロジー的に研究したが, 本報では光弹性装置により曲げ䄉維最 大屈曲部の横断面上の応力分布および長さ方向の応力分布を実測した。その結果, 応力の中立軸俚圧縮側にず

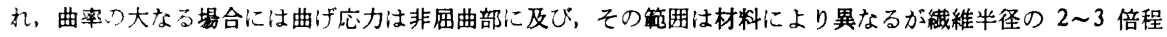
度でちった。また円形断面の㵶維を曲げると断面はダ円に近い形になることが実測されたが，その断面がダ断 円になるものとして弾性的に解析し，最大届曲部の横断面の応力の補正を行なったが，曲率が小さな場合には 断 面を円として取り扱っても大きな虽差がないことがわかった。
\end{abstract}

\section{1. むえがき}

従来瀻維のように細いるのは弾性学をあてはめると き，断面を円形とみなして解析してきたが，断面が天然 瀻維の多くのものにみられるように複雑なものはほとん ど解析不可能に近い状態であった。さらに円形の場合で も, 压㛹の際の応力ーひずみ関倸が求まらないので, 応力 分布が実測できず，曲げの際の応力の中立軸の位置は断 面の主軸に一致するものと認められてきた。しかしなが ら最近 E. Elöd ${ }^{11}$ は円形断面のナイロン瀻維を使用し, ナイロンに切込をつけ切込の反対側に曲げ，切込の深さ が直径の $2 / 3$ の深さに達したので曲げにより中立軸は中 心から直径の $2 / 3$ の位置にずれることを報告している。

さらに村上 ${ }^{2)}$ は偏光䫓微鏡により曲げ䋊維の各部の複 屈折率を測定し，応力の綎方向 (長さ方向)に作用寸る箱 囲が荷重点で止るか，それを越えてどの範囲にまで及ぶ

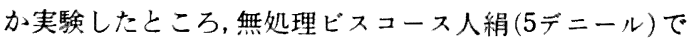

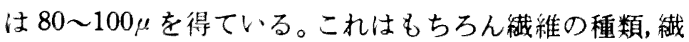
度などでも異なってくると思われるので，これらの問題 について光弹性装置を使用して応力を実測して，曲げ繊 維最大屈曲部の横断面，また縦方向の応力分布を求めた。

\section{2. 実駼}

\section{1 璂験に使用した関係理論式 ${ }^{8}$}

応力とひずみの関倸がフックの法則に従い，かつひっ ぱり弹性倸数と圧縮弹性係数とが等しい材料の一般の曲 げの場合の任意の断面の応力分布は, 曲り梁の理論によ り，N=断面に作用する垂值力， $A=$ 断面積， $M=$ 曲げ
モーメント， $\xi$ 二断面の主軸からの距離, $\rho_{0}=$ 無荷重時の 材料の曲率半径 (真值の場合 $\rho_{0}=\infty$ ), $\kappa=$ 断面係数, $\sigma=$ 断面主軸よりミの距離の部分の応力とすると

$$
\sigma=\frac{N}{A}+\frac{M}{A \rho_{0}} \cdot\left(1+\frac{1}{\kappa} \cdot \frac{\xi}{\rho_{0}+\xi}\right)
$$

である。もし梁の曲率半经 $\varrho_{0}$ が梁の梁さに比し非常に 大きいならば， $I$ を䋊維断面の 2 次モーメントとすると

$$
\sigma=\frac{N}{A}+\frac{M}{A \rho_{0}}+\frac{M}{I} \cdot \frac{\bar{s}}{\left(1+\frac{\bar{\xi}}{\rho_{0}}\right)}
$$

さらに, $\rho_{0}=\infty$ (真直の梁)ならば

$$
\sigma=\frac{N}{A}+\frac{M}{I} \cdot \xi
$$

となる。繊維のように弹性領域の少ない場合にも，中立 軸の曲率半径 $\rho$, 中立軸より $x$ の距離のひずみ $\varepsilon$ との間 には

$$
\varepsilon=\frac{x}{\rho}
$$

が成立する。

ひっぱり，圧縮両者の応力ーひずみ曲線が求まれば, 中 立軸の位置, 曲率半径は次の平衡式より一般的に求めら れる。

$$
\int \sigma d A=0, \quad \int \sigma x d A=M
$$

しかしながら㵶維の圧縮の場合の応力ーひずみ関係は測 定が困難であるので，圧縮の場合の応力ーひずみ曲線が ひっぱりのそれと等しいものと仮定すれば，中立軸の位 
置は断面の主軸と一致し $(\boldsymbol{x}=$ ミ)，?を測定すれば(4)式よ りをが，したがってまたのが求まるわけである。以上の 式はひっぱり，压縮の場合の応力ーひずみ曲線が同一で あると仮定してあるが, 複届折と応力との関倸がひっぱ りと圧縮の場合等しいと仮定して応力を実測してみた。 次に応力の測定は光弹塑性学より" $J_{\sigma}=$ 主応力の差, $\Delta n=$ 複屈折紊の差とすると

$$
\Delta n=f\left(J_{\sigma}\right)
$$

また光の通る距離(材料の厚さ) $t$ と, レタテーション $\Gamma$ との間には

$$
\Gamma=\jmath_{n} \cdot t
$$

なる関係があり， $\Gamma$ は干涉色で実測できるので, 厚さ $t$ がわかると (6), (7) 両式に上り応力。在知りうる。

\section{2 実験装置およひ実験方法}

光弾性装置として偏光顕微鏡 (E. Leitz 社製)を用い, 等傾線を消すために, 雲母板の薄片で $1 / 4$ 波長板をつけ 加えた。

光源にはナトリウムランプ(波長 $589 \mathrm{~m} \mu$ ) 使用した。 資料は東洋レーヨン製の未延伸ナイロンフィラメント (直径 $0.084 \mathrm{~mm}$ ) を恒温器で $110 \sim 130^{\circ} \mathrm{C} て ゙ 2 \sim 3$ 時間 焼鈍し, 残留応力を除去した。

資料第 1 図のごとくスライドグラス上におき, 瀻維

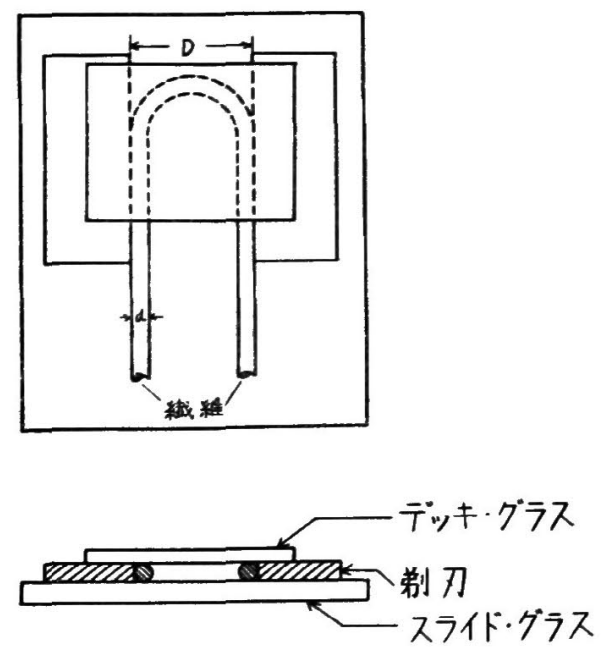

第 1 図繊維曲げ装置

よりやや厚目のカミンリ $(0.09 \mathrm{~mm})$ で両側から瀻維を押 し,かつ浮び上らぬために,デッキグラスを載せて固定す る。なお資料とグラスの間にはトリクレジルホスフェイ ト, ジプチルフタレート, ジフェニルアミンの混合液を 浸液として入れ光の分散を防いだ。曲率半径 $\rho$ は 2 枚の
カミソリの間隔 $D$, 㵶維直径 $d$ によりの=(D-d)/2 で求 めた。なお時間の要素を除去するために資料は固定して から 1 昼夜放置し，写真撮影し，印画紙上で千涉じまの位 置を測定した。しまの少ないところは白色光を用いて干 涉色を読み, 各部のリタデーション $「$ を測定した。実験 はモ,フィラメントの曲辜を種々に変えた場合と, 合撚 系をつくって熱固定し，その中の 1 本を取り出した場合 について行ない，せん断力の影響を除去するため曲げ緎 維最大届曲部の横断面について行ない, さらに縦方向の 応力分布がどんな変化をするか調へてみた。撚系は 7 本 引きそろえて 1 インチ間のヨリ数 10 と 14 の 2 種で蒸熱 にて 10 分間ぐらい処理し, ヨリを固定したものである。

\section{3. 実 験 結 果}

\section{1 繀維のはじめに有する複屈折率}

写真 1 は無荷重時のもので, 使用単色光の波長 $\lambda, n$ を 整数とすると, $\Gamma=n \lambda(=\Delta n \cdot t)$ を満足するところに干涉

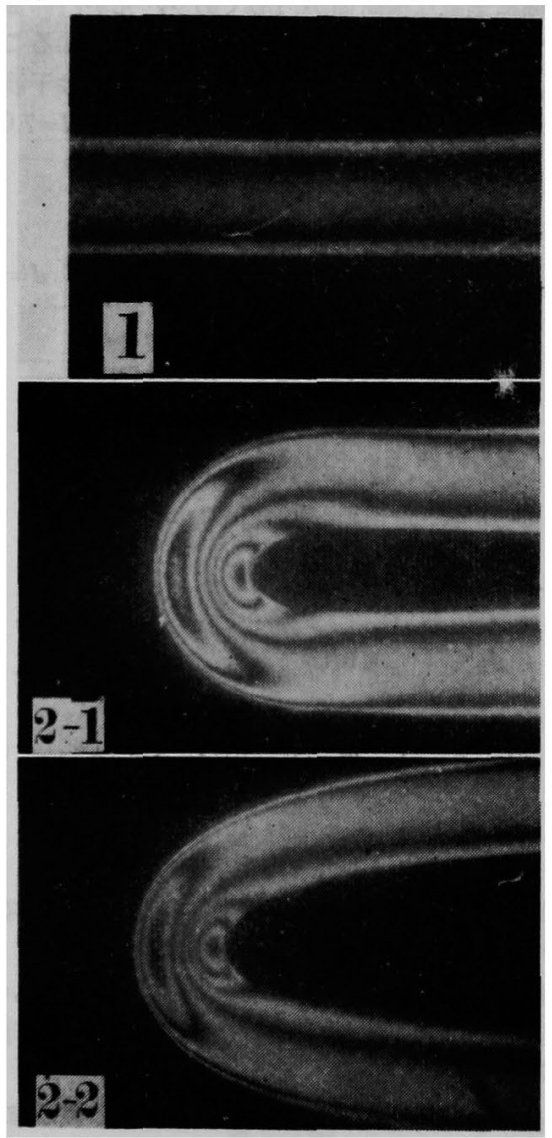

上：㵶維の初めに有した干涉じま（直径 $=0.084 \mathrm{~mm})$ (写真 $\mathbf{1})$,

中 : $d / \rho=1.1$ の場合の干涉しま(写真 2-1)， 下: $d / n=1.00$ の場合の干涉じま(写真 2-2) 


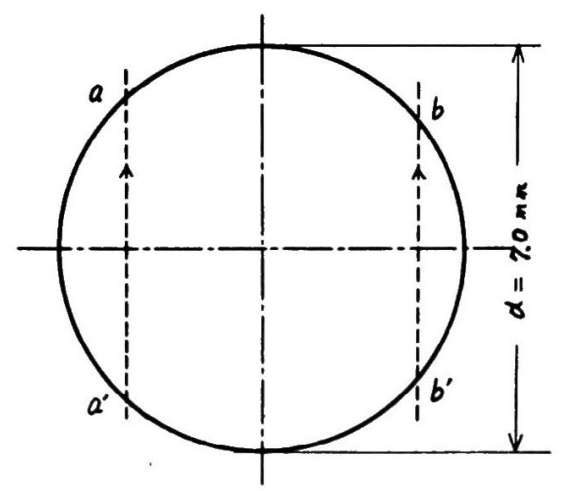

第 2 図繊 維 断 面

による黒線が現われ，本写真の場合は干涉色により $n=1$ であることがわかる。写真上の直径 $7.0 \mathrm{~mm}$ に対し, 黒 線は両端から $1.2 \mathrm{~mm}$ と $0.9 \mathrm{~mm}$ のところに現われる。 繊維の軸に垂直な横断面が円形であり, 光が内部を平行 に通過するものとみなせば, 光の通る厚さを知ることが できる。第 2 図の円は横断面を示し, $\overline{a a^{\prime}}, \overline{b b^{\prime}}$ は干涉じま の現われる部分の厚さである。図から直径 $d=7.0 \mathrm{~mm}$ に対し

$$
\overline{a a}^{\prime}=5.2 \mathrm{~mm}, \quad \overline{b b^{\prime}}=4.6 \mathrm{~mm}
$$

繊維の実径は顕微鏡のミクロメータで測定し $d=0.084$ $\mathrm{mm}$ を得ているから

$$
\begin{aligned}
t & =\overline{a a^{\prime}}=0.0840 \times \frac{5.2}{7.0}=0.0624 \mathrm{~mm} \\
t^{\prime} & =b \overline{b b^{\prime}}=0.0840 \times \frac{4.6}{7.0}=0.0552 \mathrm{~mm} \\
\lambda & =589 \mathrm{~m} \mu=589 \times 10^{-6} \mathrm{~mm} \\
\therefore \Delta n & =\frac{F}{t}=0.0095 \\
\Delta n^{\prime} & =\frac{\Gamma}{t^{\prime}}=0.0107
\end{aligned}
$$

平均をとると

$$
\Delta n_{0}=\frac{\left(\Delta n+\Delta n^{\prime}\right)}{2}=0.0101
$$

\section{2 単純ひっばり応カと複届折率}

摩擦の非常に小さい滑車を使用し, 荷重をかけて繊維 の干涉じまの位置, 直径の変化を読んだ。そして $\sigma=0$ のとき $\Delta n=0$ なるように各応力に対し $\Delta n-\Delta n_{0}=\delta \Delta n$ を対応させ, 同じ実験を 3 回行なって平均をとり示した ものが第 3 図である。

\section{3 曲け織維最大屈曲部の橫断面内の応力分布 \\ 3.3.1 無暴単䋐維}

最大届曲部の中心線の曲率半径 $\rho$ 之繊維直径 $d$ の比 d/のが異なるもの 5 種試みた。それらしま模様は写真 2

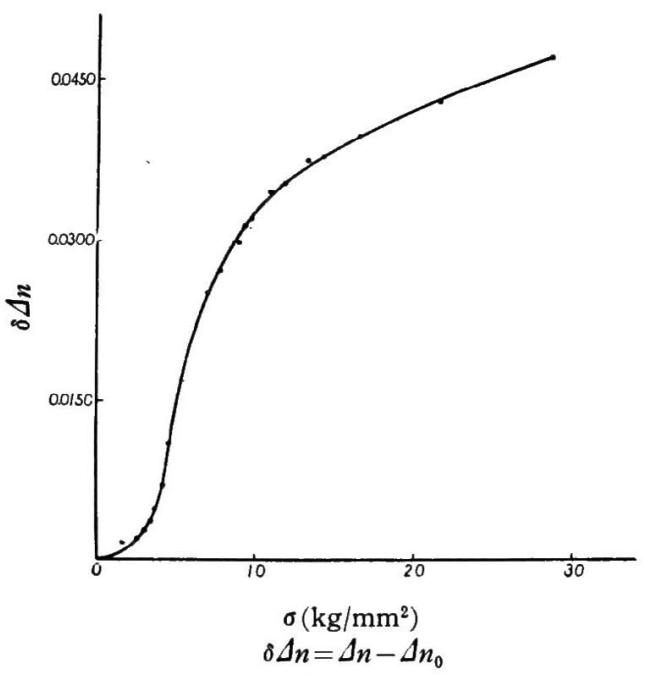

第 3 図応力-複届折曲線

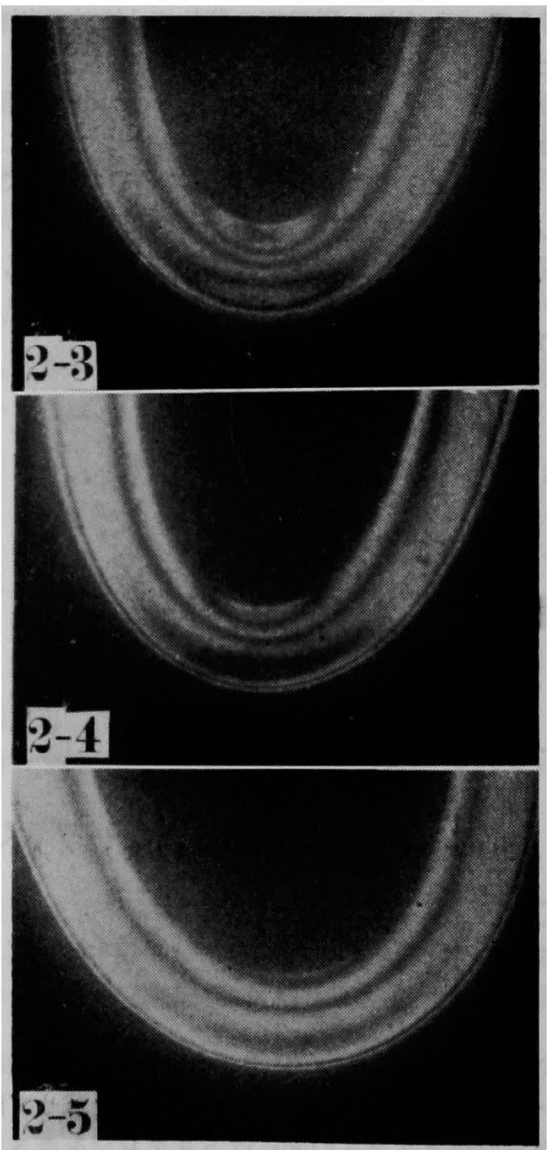

上 : $d / \rho=0.7$ の場合の干涉じま（写真 2-3）, 中 : $d / \rho=0.6$ の場合の干涉じま（写真 2-4), 下: $d / \rho=0.45$ の場合の干涉じま（写真 2-5) 


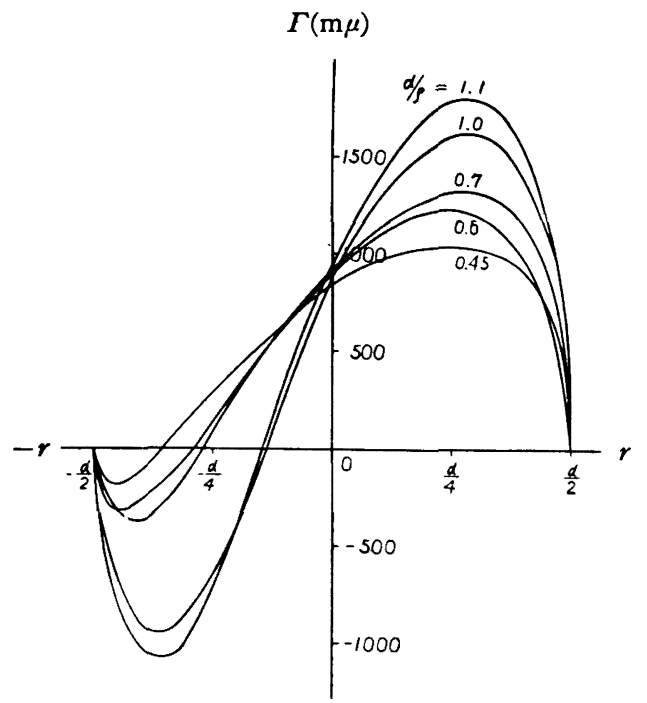

第 4 図 届曲緎維横断面の中心からの距䆶 $r$ と リタデーション $\Gamma$ の関俰

である。横断面内の応力を求めるに洨，まず各部のリ夕 デーションを知らねばならぬので，写真より干涉じまの 位置を測定し, 瀻維の中心からの距㒕 $r$ と $\Gamma$ の関係を求 め，第 4 図に示す。またしまの少ないこころは白色光に よる干涉色を基にして $\Gamma$ を求めた。第 4 図より Inを $\Delta n_{0}$ と同様にして求め， $\sigma-J_{n}$ 曲線より求めたのか゚第 5 図であり,正号はひっぱり側を, 負号は圧縮側を示す。

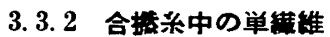

加撚により単臓維は曲し，それが熱処理により固定 されるから，3.3.1 の場合のよ5に曲げる前の複屈折率 が均一とみなすことはできない。晴曲の外側は張力によ り $\Delta n$ が増加し,内部は圧樎により $n n$ が堿少している。 曲げた後の $\Gamma$ から前の $\Gamma^{\prime}$ を引いて厚さで割れば容易に $\Delta n$ が計算できる。写真 3 はヨり数/インチがそれぞれ 10,14 のもので (i), (i') は解きほぐしてはあるが曲泫る前

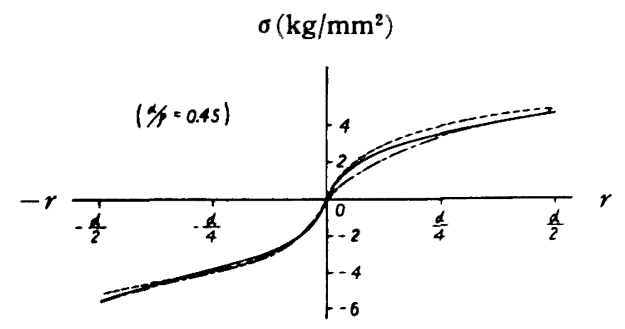

䓒 5-1 図届曲繊維横断面上の応力分布

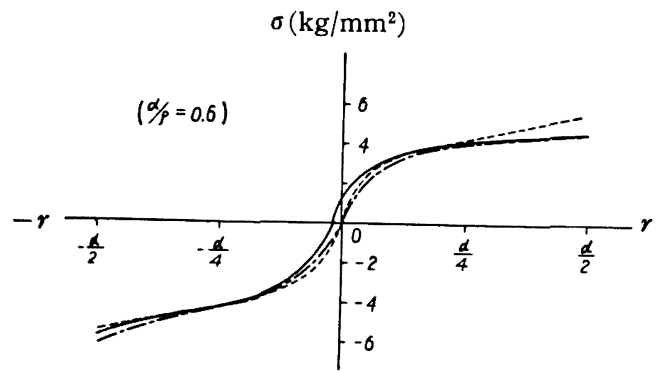

第 5-2 図

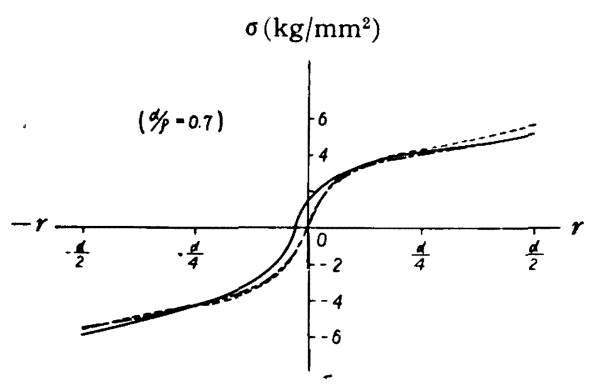

第 5-3図

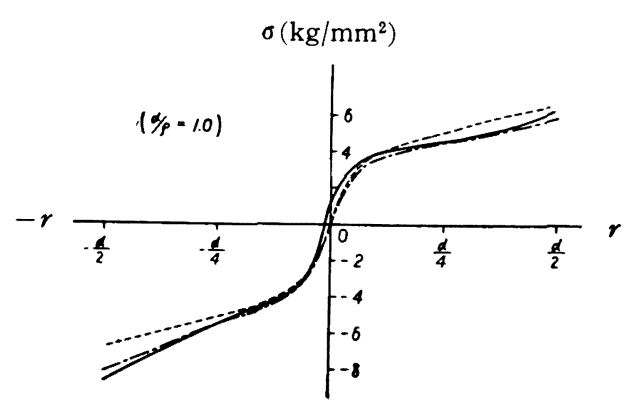

第 5-4 図

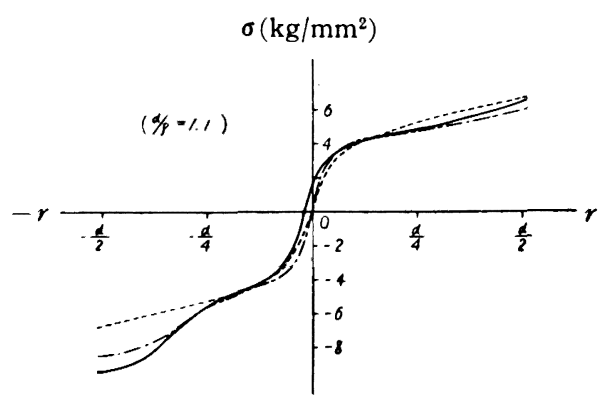

第 5-5 図 


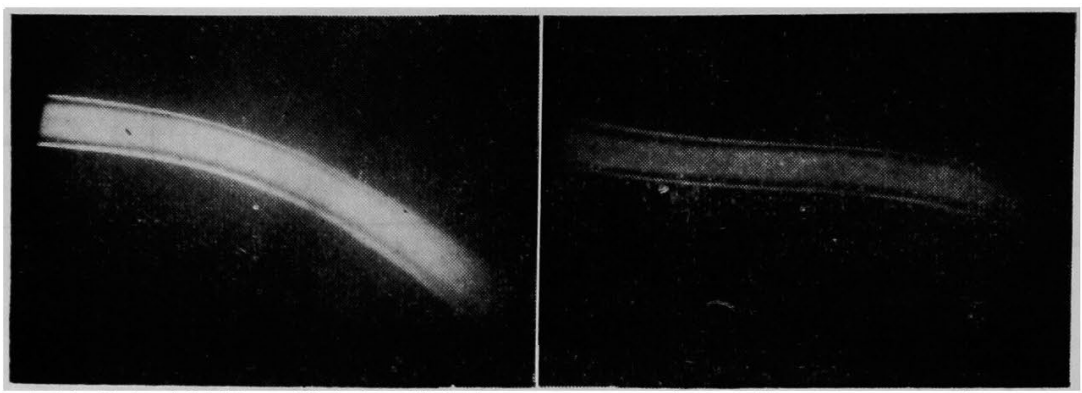

写真 3-1 $10 T /$ in の然杀中の単繊維の 初めに有した干涉じま
写真 3-1' $14 T /$ in の撚采中の単繊維の 初めに有した干渉じま

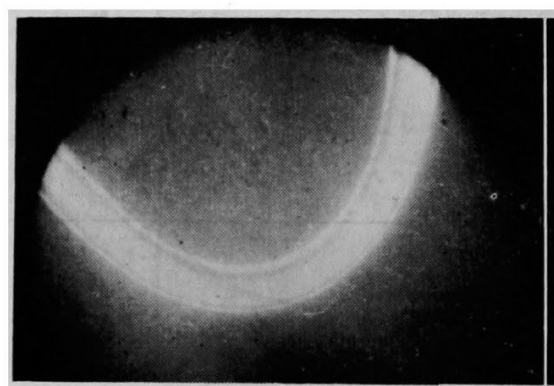

写真 3-2 3-1 の $d / \rho \approx 0.3$ の場合の干 涉じま

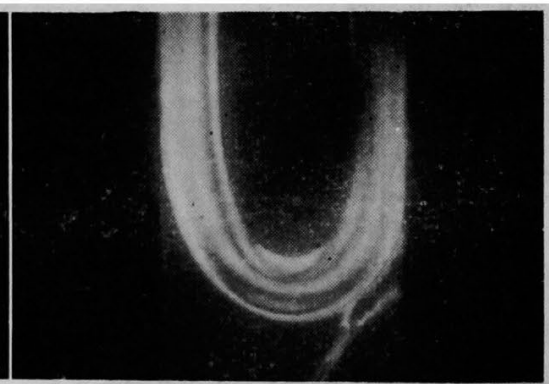

写真 3-2' $3-1^{\prime}$ の $d / \rho \approx 0.7$ の場合の干 涉じま

あり，点楾は曲げる前に有したリタデーション $\Gamma^{\prime}$ であ り, 曲げにより増加したリタデーション $\Delta \Gamma\left(=\Gamma-\Gamma^{\prime}\right)$ は 両曲線の差である。 $\Delta n=\Delta \Gamma / t$ より $\Delta n$ を求めると $\sigma-$

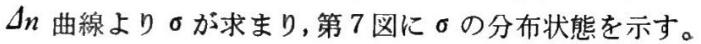

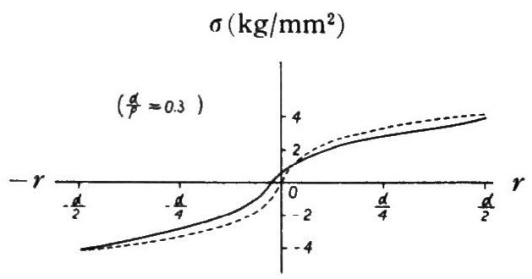

第 7-1 図 ヨリ構造をもつ繊維の届曲部横断面 上の応力分布 $(10 T /$ in $)$

第 6-1 図 (ii)の届曲部横断面の中心からの距離 $r$ とリタデーション $\Gamma$ の関倸

$\Gamma(\mathrm{m} \mu)$

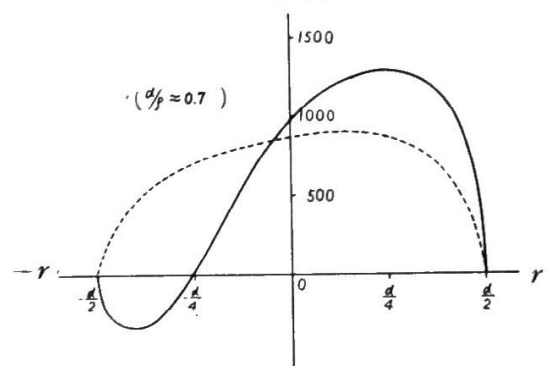

第 6-2 图（ii'）の屈曲部横断面の中心加らの距雄 $r$ とリタデーション $\Gamma$ の関倸

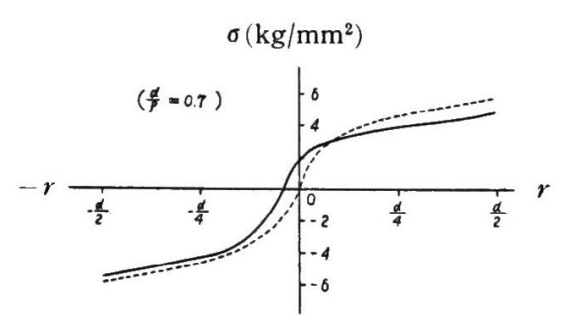

第 7-2 図 ヨリ椿造をるつ絨維の風曲部横断面 上の応力分布 $(14 T /$ in $)$

\section{4 緃方向の応力分布}

縦方向には応力がいかなる分布をし，頂点よりどれだ 


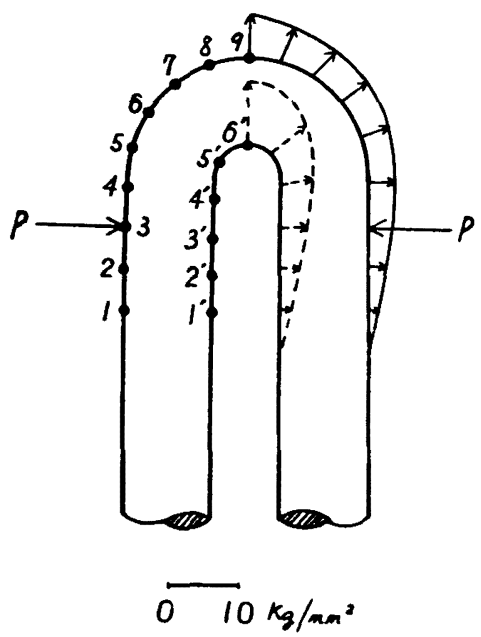

第 8 図里曲㵶維の長さ方向の 店力分布, $d / \circ=1.1$

け離れた籁囲まで及んでいるか $d / \rho=1.1$ について調べ る。本来なら第 8 図の $1,2,3 \ldots 9,1^{\prime}, 2^{\prime}, 3^{\prime} \ldots 6^{\prime}$ の点 を測定すべきであるが，周辺では厚さ $t$ が 0 となり，し まが現われないことにより $J n$ は求まらないから, 少し 内側の点の $J_{n}$ を測定した。ひっぱり側では $1 \lambda$ の干涉 じまの現われる部分の厚さを測り $\Delta n$ を求める。圧縮側 ではやや内側にずれるが $1^{\prime}, 2^{\prime}, 3^{\prime}$ は $1 \lambda, 4^{\prime}$ は $0 \lambda, 5^{\prime}$, $6^{\prime}$ 、は $-1 \lambda$ を利用して計算した。この計算より求めた 応力分布を示したものが第8図である。

\section{4. 考察}

（1）横断面内の応力を平面的に取り扱い, 第 9 図の $z-x$ 面に垂直に光が通るものとし,曲沃は $z-ル$ 面で行なわれ

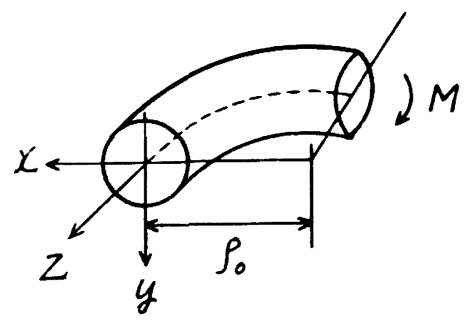

第9図曲げ面

るものとすれば, $\sigma$ は $x$ のみに依存し, $y$ には関倸ないも のとして取り扱ったが, 円形断面の曲り梁の理論による $と^{5)}$ 横断面に垂直な応力 $\sigma_{z}$, および面に垂直に作用する 応力 $\sigma_{x}$ 村, $M=$ 曲げモーメント, $\nu=$ ポアッンン比, $d / 2$ $=$ 断面半径, $\rho_{0}=$ 材料の曲げる前の曲率半径とすると

$$
\begin{aligned}
\sigma_{z}= & -\frac{4 M}{\pi\left(\frac{d}{2}\right)^{4}} \cdot\left[x+\left\{\left(8+10 \nu+4 \nu^{2}\right) x^{2}\right.\right. \\
& \left.\left.-\left(6 \nu+4 \iota^{2}\right) z^{2}-(2+\nu)\left(\frac{d}{2}\right)^{2}\right\} / 8(1+\nu) \rho_{0}\right] \\
\sigma_{x}= & -\frac{M}{4 \rho_{0}(1+\nu) \pi\left(\frac{d}{2}\right)^{4}} \cdot\left[(7+6 \nu)\left(x^{2}-\left(\frac{d}{2}\right)^{2}\right)+(5+2 \nu) z^{2}\right]
\end{aligned}
$$

である。しかし $\rho_{0} \gg x, y, d / 2$ であるから $z=0$ において は,

$$
\begin{aligned}
& \sigma_{z}=-\frac{4 M}{\pi\left(\frac{d}{2}\right)^{4}} \cdot x \\
& \sigma_{x}=0
\end{aligned}
$$

ゆえに

$$
\Delta n=f(\Delta \sigma)=f\left(\sigma_{z}-\sigma_{x}\right) \cong f\left(\sigma_{z}\right)
$$

（2）第 5,7図によると曲率半径の大きいとき中立軸の 内側への移動少なく(たとえば $d / \rho=0.45$ の場合ほとん ど移動なく), 曲率半径の小さいとき移動大きい(たとえ ば $d \mid \rho=1.1$ の場合移動明眿)。また応力の絶対值も内縁 と外縁では曲率半径が大きいときは等しいが，小さいと きはかなり異なってくる。このことは, 曲梁の理論によ ると, 曲げモーメント $M$ による応力 $\sigma は$ (1) 式と同様の 記号を使用すると

$$
\sigma=\frac{M}{A \rho_{0}} \cdot\left(1+\frac{1}{\kappa} \cdot \frac{\xi}{\rho_{0}+\xi}\right)
$$

したがって， $\sigma=0$ である中立軸は $\xi=0$ でなく $\bar{\xi} に$ 移 動する。その衣は

$$
\bar{\xi}=-\frac{\kappa}{1+\kappa} \cdot \rho_{0}
$$

となる。一般にのの分布は $\left(1_{\mathrm{a}}\right)$ 式で示されるよらに双曲 線分布をなし， $\left(1_{\mathrm{b}}\right)$ 式からわかるよ5に中立軸は内側の 方へ移動し，応力も絶対值で内縁の方が增加するといら 理論から考えてらなずける。

(3) 頂点以外の各部の横断面ではせん断力が影響する ので, 写真4により等傾線を求めた。その結果は等傾線 が非常に太く出てきて, 求めた主応力線は不正確なもの となったが，主応力の方向の傾向は第 10 図に示してあ る。曲莩が大きくなると横断面の変形も考虑しなけれ ばならない。それゆえ, 曲げが弾性領域内にあるものと し, 曲げる前の繊維半径を $d / 2$, 曲率半径を $\rho$, ポアッソン 比をっとすると最大届曲部の横断面は凝似ダ円となり

$$
\begin{aligned}
& \text { 長径 }=\frac{(d+\Delta d)}{2}=\frac{d}{2}\left(1+\frac{\nu d}{4 o}\right) \\
& \text { 短径 }=\frac{\left(d-J_{d}\right)}{2}=\frac{d}{2}\left(1-\frac{\nu d}{4 o}\right)
\end{aligned}
$$




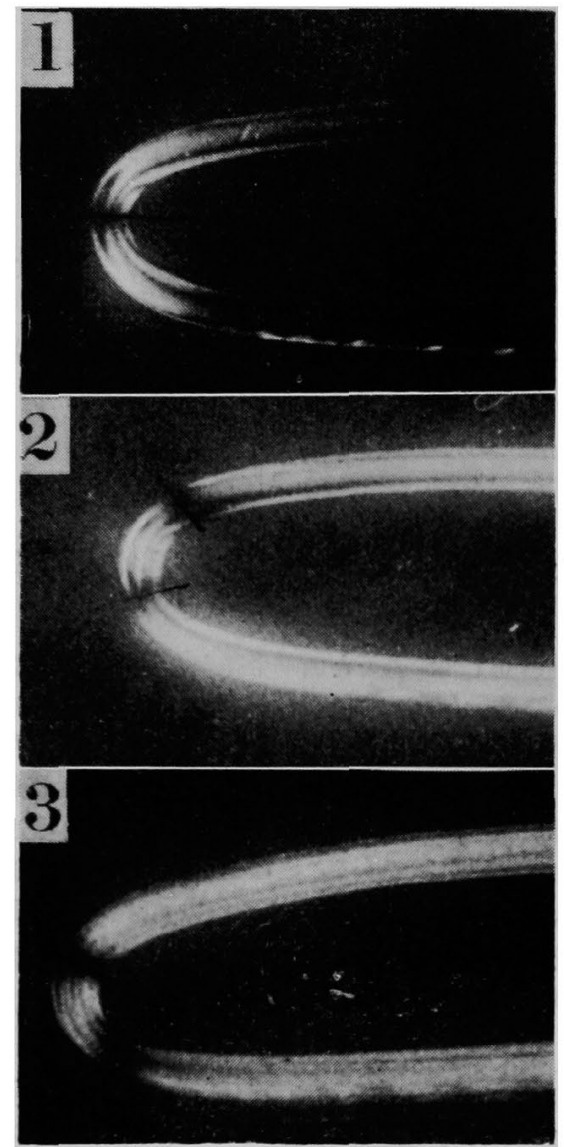

上：曲げ繊維の等傾線 $\left(0^{\circ}, 90^{\circ}\right)$ (写真 4-1), 中: 曲げ繊維の等傾線 $\left(30^{\circ}\right)$ (写真 4-2), 下: 曲沃繊維の等傾線 $\left(60^{\circ}\right)$ (写真 4-3)

で表わされる 厚さを求め, これから各部分の応力を求めた指暗第 5 図の鎖楾に示す。これより断面の变形による応力の分布 は弾性変形の場合に注あまり問題とならず，ただ曲率半 径が小になると中立軸から雔れたところが異なるが，断

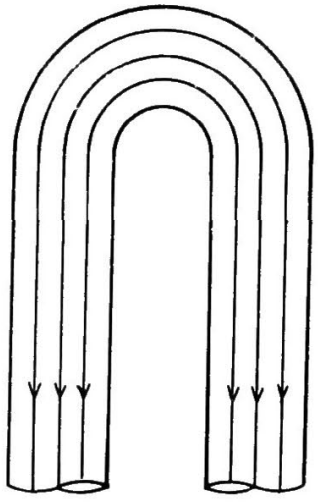

第 10 図曲げ繊維の主応力の方向

面を円として取り扱っても大きな誤差はない。このこと はアミランガットで $d / \rho \fallingdotseq 1.4, d / ! \fallingdotseq 1.2$ に曲げ, その最大 屈曲部の横断面の写真 5 をとってみたところ, 前者はダ 円よりむしろそら豆に近い形をしており，後者はダ円と なる。これは材料の弹性係数に関係すると思うが $d / \rho \fallingdotseq$ 1.0 以下ならば円として取り扱っても誤差が少ないこと （詳しくは第 6 報を参照されたい）と考え含せれば妥当で ある。

（5）中立軸が図心にあるものとし中立軸より $x$ の距離 にあるひずみ $\varepsilon=x / 0$ より求め, 応力ーひずみ曲線よりさ らに応力。を求めて第 5,7 図に点線で示した。然糸中の 単䋗維の場合はややずれるが，他は中立軸付近を除いて 大体一致している。

(6) 曲げ繊維の縦方向の応力分布は断面半径の $2 \sim 3$ 倍に及ふとと村上は実験で求めているが, 彼の理論による と理論的な平均伸びは約 $40 \%$ であるが，われわれの用 いた材料では $100 \%$ 以上も伸張が可能であるが，半径の 2〜3 倍程度の範囲にまで及んでいることがわかった。

（7）実験に末延伸ナイロンを使用した理由は，あまり 細、纎維は曲げ固定が困難であり, 写真の解析が困難で あること,さらに延伸したもので太いものは光の透過が 困難であったことなどの技術的の理由によったものであ

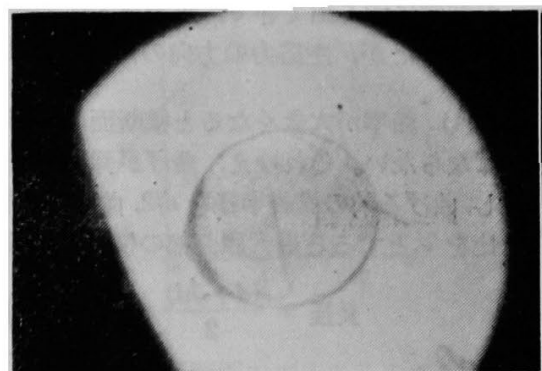

写真 5-1 届曲ナイロンガット横断面の 形状, $d / \rho \fallingdotseq 1.2$ (屈曲前の直径 $=1.00 \mathrm{~mm}$ )

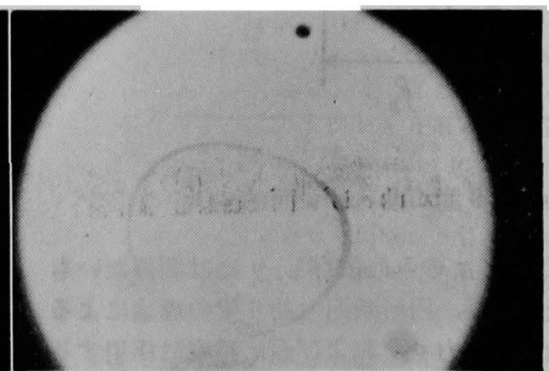

写真 5-2 届曲ナイロンガット横断面の 形状, $d / \rho \doteqdot 1.4$ 
るが，この材料にも応力ーひずみ曲線(第11図)にみるご とく，伸びが $150 \%$ 以上にもなり，普通の繊維材料とは

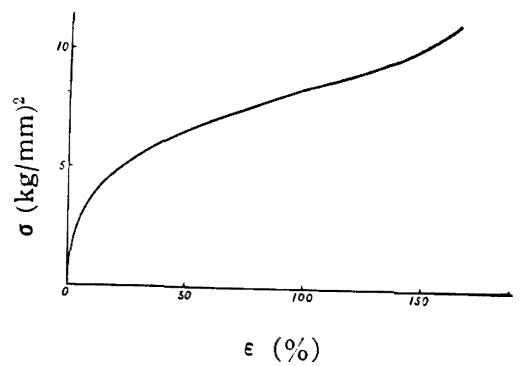

第 11 図末延伸ナイロン繊維の応力ーひずみ曲線

かなり異なってくることと, 非常にクリープを起しやす いために, 時間の要素を入れないために曲げてから一定 時間(1 昼夜)を決めて比較した。これについては実験で 確かめるべきであるが, 堀尾, 近土 ${ }^{7}$ が酢酸瀻維素皮膜で 実験したところ，忘力緩和しても複届折度はそれほど大 きな変化はしないと報告しているつで，特別に実験を行 なわなかった。

\section{5.むすひ}

(1) 複届折率と応力の関倸がひっぱりと圧縮とで等し いものと仮定して曲げ緎維の汒力分布を求めると, 応力 の中立軸は圧縮側にずれる。

(2) $d / \rho<1.0$ なら屈曲部の断面形は円と考えても大き な誤差がないことがわかった。

(3) 曲率半径 $\rho$, および中立軸から距離 $x$ の点のひず
み $\varepsilon$ は $\varepsilon=x / \rho$ より求められ,さらに $\sigma-\varepsilon$ 曲線より求 た $\sigma$ の分布は， $\Delta n-\sigma$ から求めた $\sigma$ の分布と大体一致! る。一般に, 材料では最大ひっぱり応力または圧縮応 が問題となるのであるから， $\varepsilon=x / \rho$ より $\varepsilon$ を求め, $\sigma-$ 曲線から $\sigma$ 求めて使用しても良いことがわかる。

(4) $100 \%$ 以上の伸張可能の材料でも，曲率大なる去 合には曲げ応力が非屈曲部に及び, その範囲は繊維半良 の最大 2 3 倍程度であった。

付 記：ご批判をいただいた科研 西田正孝博士，本学 呉祐吉教授，複届折率についてご指導を得た阳田教授，石川目 教授および試料を御惠与下さった東洋レーヨン中央研究所 沢宏氏，および実験に協力していただいた西村正孝，久保田隆 両君に感謝致します。

\section{文献}

1) E. Elöd: Industrie Chimique Belge., 20, 3 ! (1955)

2）村上：纎維工試菓報，34，56(1955)

3) 湯浅: 材料力学 (下), 344 365(昭和 26 年)

4) 応力測定技術研究会編: 応力測定法, 472 67: (昭和 30 年); 湯浅: 材料力学(下), 420 494,

5) 倉西: 弾性学, 227 (昭和 23 年)

6)鈴木：第 7 回高分子学会講演要旨, 116(1958)

7) 堀尾, 近土：材料試験, 6, No. 43, 256 259(1957, その他一般的に参考にしたものとして

8) 小原：顕微鏡による繊維研究法 (昭和 11 年)

9) A. Nadai : Plasticity (1931)

10) 西田：高分子, 7, No. 74, 71〜76(1958)

11) 福原：応用光弾性学 (大正 15 年)

\title{
Mechanics on the Crease of Fabrics
}

\section{Stress Distributions in Bent Fiber}

\section{By Megumu Suzuki*}

\begin{abstract}
As the model of a bent filament in a creased fabric a nylon filament was used and the stress distribution in the cross section of the bending plane and in the longitudinal direction was studied. As the results, it is known that the neutral axes exist on the compression side, and the bending stress give an effect on the non-bending part in the longitudinal direction, 2 to 3 times of the fiber radius, although the effect varies with the kind of the fiber and its denier. When a fiber of circular section is bent, the cross section of the bending plane is in the form of ellipse and so the stresses in the cross section of the bending plane are corrected from the study of elasticity. In this paper, however, it is assumed that the same relation between the double refraction and the stress holds good in the tension side as similarly as in the compression side.
\end{abstract}

\footnotetext{
* Faculty of Textile and Sericulture Shinshu University (500 Tokiire, Ueda, Nagano)
} 